\title{
Drug Sensitivity Test for Clinical and Sub Clinical Mastitis
}

\author{
N. S. Gangurde ${ }^{*}$, D. S. Shinkar, V. V. Potdar, Jayanti Mori and Alok Juneja \\ Disease Investigation Laboratory Vihar, BAIF-DURDA, \\ Tal. Mansa, Dist. Gandhinagar, India \\ *Corresponding author:
}

\begin{abstract}
A B S T R A C T
\section{Keywords}

Drug Sensitivity Test, Sub Clinical Mastitis

Article Info

Accepted:

22July 2019

Available Online:

10 August 2019

Bovine mastitis, the most significant disease of dairy herds. It has a huge effect on dairy farming economics due to the reduction in milk production and treatment cost. The severity of this problem can be classify into subclinical, clinical and chronic form and its degree is dependent on the nature of the causative pathogen, age of animal, immunological status, health status and lactation status of the animal. Subclinical mastitis is difficult to detect due to absence of any visible indications. Chronic mastitis is a rarer form of the disease but result in persistent inflammation of the mammary gland. Therapeutic success of mastitis depends mainly on accurate diagnosis, severity of udder pathology, drug selection, and relevance of route of administration, supportive treatment and elimination of predisposing factors (Hossain et al., 2017). This review will highlights the key antibiotics for treatment of clinical and subclinical mastitis as a prospective approach for control of mastitis in dairy animals.
\end{abstract}

\section{Introduction}

The drug resistant bacteria develop or acquire techniques to bypass the action of antibiotics. When the bacteria develop this protective mechanism against many antibiotics they are generally termed as drug resistant bacteria. Affected milk samples are tested against numerous antibiotics. Antibiotics which effectively inhibit growth of bacteria in test media are considered as effective antibiotics. So the success rate of treatment depends on the choice of the appropriate antibiotics to which the pathogenic bacteria is sensitive. Drug sensitivity test provides information about which antibiotic is effective and which are not. Mastitis might be such kind of major problem at field level because appropriate antibiotic therapy is not initiated and day by day the problem becomes completely incurable. Use of many antibiotics at regular interval for the same condition to cure may hamper the milk production without any significant result. This test is performed invitro and measure the growth response of an pathological organism to a particular drug or drugs. In-vitro testing of bacterial culture with antibiotics to determine susceptibility of bacteria to antibiotic therapy.

\section{Importance of Antibiotic Sensitivity Test}

It is a laboratory test which determine how antibiotic therapy is against a bacterial 
infection. It will control the use of antibiotics in clinical practice.

Testing will assist the clinician in the choice of drugs for the treatment of infection.

To determine the degree of sensitivity of resistance of pathogen in suspected milk samples to an appropriate range of antimicrobial drugs.

The study was carried out on drug sensitivity pattern from milk samples suspected for mastitis in DS LABORATORY VIHAR. The present study was design to examine antimicrobial resistance in bovine clinical and sub clinical mastitis with the aim to generate data helpful for field veterinarian in the early treatment and to provide information on trends in resistance to aid in developing the antimicrobial usage policy.

\section{Materials and Methods}

Milk samples were collected aseptically from local animal health centers with the help of Veterinary officers of Dudhsagar Dairy Mehsana. First California Mastitis Test was done to conform the mastitis. Drug sensitivity test was carried out to find out the effective antimicrobial for clinical \& subclinical cases of mastitis. The antimicrobials commercially available in market as anti-mastitis preparations were test for their in vitro efficacy.

\section{Procedure for Drug sensitivity test}

Incubate sample at $37^{0} \mathrm{C}$ for $24 \mathrm{hrs}$ in Brain Heart Infusion brothfor better bacterial growth.

Load Sample on Mulear Hilton Agar Plate and put different antibiotic discs

Keep it in incubator for $37^{\circ} \mathrm{C}$ for $24 \mathrm{hrs}$.

Observe zone of inhibition

Prepare smear from the bacterial growth and stained by Giemsa Stain for identification of Bacteria (Gram +ve or Gram -ve).

\section{Reading}

\section{Sensitive}

In this case a clear, circular halo (technically known as a "plaque" or zone of inhibition) will appear around the antibiotic disk, indicating absence of bacteria. The antibiotic has inhibited their growth and or killed them meaning that this particular antibiotic should be effective against the infection.

\section{Intermediate}

A somewhat cloudy plaque indicates that not all the bacteria in the area around the disk have been killed. This means that there are some members of the bacterial population that are sensitive to this particular antibiotic but others that are genetically immune to its effect.

\section{Resistant}

In this case there will have no discernable plaque around the disk meaning that the bacteria are growing normally even in the presence of the antibiotics.

\section{Results and Discussion}

In DS Laboratory Vihar758 positive milk samples were tested for drug sensitivity. These samples showed highest sensitive zone for following antibiotics

Total 91 samples didn't show sensitivity zone to all antibiotics mentioned in table. Complete resistance to all the type of antimicrobial agents being tested characterized yeast mastitis. This is due to the fact that yeast has thick wall with starch on which antimicrobial has no effect Chuang-Shih Te et al., (2002) 
Table.1

\begin{tabular}{|l|c|l|c|}
\hline Antibiotics & $\begin{array}{c}\text { No of Samples } \\
\text { Showed } \\
\text { Sensitivity }\end{array}$ & Antibiotics & $\begin{array}{l}\text { No of Samples } \\
\text { Showed } \\
\text { Sensitivity }\end{array}$ \\
\hline Gentamicin (GEN) & 154 & Ceftriaxone & 133 \\
\hline Enrofloxacin (EX) & 87 & Ciprofloxacin (CIP) & 85 \\
\hline Streptomycin (S) & 48 & Amoxycillin (AM) & 48 \\
\hline $\begin{array}{l}\text { Co-Trimoxazole } \\
\text { (COT) }\end{array}$ & 33 & Penicillin (P) & 23 \\
\hline Oxytetracyclin (O) & 16 & Levofloxacin (LEV) & 15 \\
\hline Cephalothin (CEP) & 12 & Neomycin (N) & 9 \\
\hline Methicillin (MET) & 4 & $\begin{array}{l}\text { NO SENSITIVITY } \\
\text { TO ALL }\end{array}$ & 91 \\
\hline & & ANTIBIOTICS & \\
\hline
\end{tabular}

High proportion of samples had shown drug sensitivity towards Gentamicine, Ceftriaxone, Enrofloxacillin \& Ciprofloxacillin. So to control infection these drugs were recommend as a strategy to minimize spread of resistant organism at field level and got excellent result.

The result of antimicrobial susceptibility testing should be combine with clinical information and experience when selecting the most appropriate antibiotics in mastitis. It is just a guideline for the physicians in choosing antibiotics.

\section{References}

Chuang S T, Shyu CL, Chan PWJ \& Fung H P (2002): Taiwan Vet J 28: 94-98

Hossain MK, Paul S, Hossain MM, Islam MR, Alam MGS, Bovine mastitis and its therapeutic strategy doing antibiotic sensitivity test, Austin Journal of Veterinary Science and Animal Husbandry, 2017: 4(1); 1-12

\section{How to cite this article:}

Gangurde N. S., D. S. Shinkar, V. V. Potdar, Jayanti Mori and Alok Juneja. 2019. Drug Sensitivity Test for Clinical and Sub Clinical Mastitis. Int.J.Curr.Microbiol.App.Sci. 8(08): 2948-2950. doi: https://doi.org/10.20546/ijcmas.2019.808.339 